
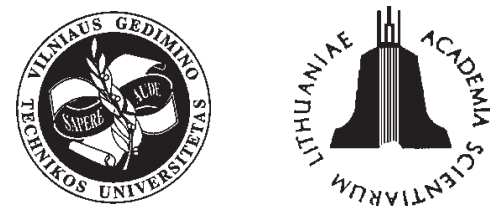

JOURNAL OF CIVIL ENGINEERING AND MANAGEMENT

http:/www.jcem.vgtu.lt

2005, Vol XI, No 1, 33-37

\title{
INFLUENCE OF LONGITUDINAL REINFORCEMENT ON DEVELOPMENT OF NORMAL CRACKS
}

\author{
Vidmantas Jokūbaitis, Petras Pukelis \\ Dept of Reinforced Concrete and Masonry Structures, Vilnius Gediminas Technical University, \\ Saulètekio al. 11, LT-10223 Vilnius, Lithuanian. E-mail: gelz@st.vtu.lt
}

Received 28 Sept 2004; accepted 07 Jan 2005

\begin{abstract}
Using a model of normal crack propagation in reinforced concrete members, an analytical expression is presented for the stress intensity factor defining the intensity of stress in area at the crack tip. This factor is in linear relationship to the stress in tensile reinforcement, which can be determined by different methods. The analysis performed indicates that there is a direct relationship between the stress intensity factor and normal crack depth, when a stable and chaotic propagation of cracks in the initial cracking stage of the member terminates. In addition, expression of this relationship depends significantly on reinforcement ratio of underreinforced beams.
\end{abstract}

Keywords: stresses, tensile reinforcement, normal cracks, stress intensity factors.

\section{Introduction}

Many reinforced concrete structures in operation are with cracks. The greatest stresses in their tensile reinforcement are in normal cracks since there the greatest quantity of energy is consumed for destruction of concrete structure at crack tips. The energy used for formation of new surfaces of cracks can be equivalently replaced the stress intensity factor defining the stress in area at micro-crack tip. According to proposed model for normal crack propagation in reinforced concrete beam [1], one tip of normal crack coincides with the centre of tensile reinforcement restraining the crack. Stress in tensile reinforcement increases with propagation of crack in concrete towards the neutral axis of reinforced concrete member and value of stress intensity factor $K_{I}$ increases as well. As soon as this value reaches the critical one, $K_{I C}$, failure of underreinforced concrete member in normal crack starts, ie, yield stress value in tensile reinforcement occurs.

Many theoretical and experimental investigations have been performed in formation and propagation of cracks in cement concrete using criteria of the fracture theory during the last 20-30 years [1-4]. But there are comparatively quite few investigations of propagation of cracks in reinforced concrete (especially with clarification of the role of tensile reinforcement for intensity of cracks propagation), in which fracture mechanics of solids is used [1, 5-8].

In this article a method for calculation of stress intensity factor for reinforced concrete is proposed, in which the main role in stabilisation of propagating cracks in reinforced concrete beams is performed by tensile reinforcement. With relevant reliability regulation of the critical stress intensity factor $K_{I C}$ it is possible to determine safe limits (when $K_{I} \leq K_{I C}$ ) for operation of reinforced concrete member.

\section{Methods for determination of stress intensity factor}

According to the model of normal crack propagation in reinforced concrete member [1] crack in concrete propagates in one direction only, towards the neutral axis. Propagation of crack is restrained by tensile reinforcement, which is conventionally assumed uniformly distributed along the width of cross-section as a solid strip. According to this model, stress intensity factor

$$
K_{I}=1,6 \sigma_{s} \frac{\sqrt{t}}{\alpha}
$$

where $\sigma_{s}$ - reinforcement stress; $t=\left(A_{s} / b\right)$ - thickness of solid reinforcement strip; $\alpha\left(=\frac{E_{s}}{\varphi E_{c m}}\right)$ - reinforcement and concrete modular ratio $(\varphi \approx 0,85)$.

In this case factor $K_{I}$ (and its critical value $K_{I}$ ) is not a parameter for reinforcing steel as for a separately taken material. The factor evaluates influence of tensile reinforcement and indirectly of transverse strains of concrete in compression zone on restraint of crack in rein- 
forced concrete member.

Reinforcement stress in normal crack [1]:

$$
\begin{aligned}
\sigma_{s}= & {\left[\frac{\left(M_{t o t}-\Delta M\right)\left[0,75\left(h_{c r}-d_{1}\right)+h_{c t}\right]}{I_{1}}-\frac{N_{t o t}}{A_{1}}\right] . } \\
& \frac{\pi \alpha}{4 \omega} \sqrt{\left(h_{c r}-d_{1}\right) / t} .
\end{aligned}
$$

Putting of stress $\sigma_{s}$ value in formula (1), results in such an expression for factor:

$$
\begin{aligned}
K_{I, 1}= & 1,26\left[\frac{\left(M_{t o t}-\Delta M\right)\left[0,75\left(h_{c r}-d_{1}\right)+h_{c t}\right]}{I_{1}}-\frac{N_{t o t}}{A_{1}}\right] . \\
& \frac{\sqrt{h_{c r}-d_{1}}}{\omega} .
\end{aligned}
$$

Here $M_{\text {tot }}=M-P e_{p}, N_{\text {tot }}=P \pm N(P$ ir $N-$ precompression and axial forces in the member; compression force $N$ is taken with plus sign; $e_{p}$ - eccentricity of force $P$ in relation to cross-sectional centre); $\Delta M=N_{\text {tot }}\left(y-y_{1}\right) \quad($ Fig 1$) ; \omega=125 \rho$, when reinforcement ratio $\rho=A_{s} /(b d)<0,008$ and $\omega=1$, when $\rho \geq 0,008 ; A_{1}$ ir $I_{1}$ - area and second moment of equivalent concrete cross-section, depth of which is $h_{1}$, in relation of cross-section centre superposed with the neutral axis; values $d_{1}, y, y_{1}, h_{c r}, h_{c t}$ see in Fig 1 .

Depth of design cross-section $h_{1}$ is determined by the condition:

$$
h_{c r}-d_{1}+h_{c t}=S_{1} / A_{1},
$$

where $S_{1}$ - the first moment of area $A_{1}$ in respect to tensile reinforcement centre.

Depth of concrete zone in tension above crack $h_{c t}$ can be determined from empirical formula [1]:

$$
h_{c t}=0,00012 d_{1} \sqrt[3]{d_{s}} \lambda_{1} \frac{h_{c r}}{w}
$$

where $d_{s}$ - reinforcement bar diameter, mm; $w$ - crack width at the level of reinforcement centre; $\lambda_{1}$ - coeffi- cient for evaluation of effect of tensile flanges in crosssection to the depth hct, of bond between reinforcement and concrete etc [1]. Average deviation of values $h_{c t}$ calculated according to (5) from experimental ones is ($0,4 \%$ ), standard deviation from the average value $-26 \%$. Formula (5) is valid, when ratio $d_{1} / h=0,08 \div 0,22$ and reinforcement diameter $d_{s} \leq 25 \mathrm{~mm}$.

Stress in tensile reinforcement can be calculated by the method proposed by A. Rozenbliumas [7], in which functional relationship between stresses, acting forces, measured normal crack depth and geometrical parameters of cross-section was established and approved experimentally, when crack depth $h_{c r, a c t}>h_{f 1}$ :

$$
\left.\begin{array}{l}
h_{c t} \approx \frac{\left(I-S h_{c r, a c t}\right)-\left(S-A h_{c r, a c t}\right) d_{1}}{\left(\frac{M}{2 f_{c t}}+S\right)-\left(\frac{N_{t o t}}{2 f_{c t}}+A\right) d_{1}}, \\
\sigma_{s} A_{s}=\left[\frac{S-A h_{c r}}{h_{c t}}-\left(\frac{N_{t o t}}{2 f_{c t}}+A\right)\right] 2 f_{c t}
\end{array}\right\},
$$

here $M$ - bending moment in respect of the edge of crosssection subjected to the greatest tension; $A-$ cross-sectional area of concrete excluding area of concrete within the measured depth of the crack $h_{c r, a c t} ; S$ and $I-$ the first and the second moments of area $A$ in respect to the edge of the cross-section in the greatest tension; $f_{c t}$ tensile strength of concrete; $\alpha=\frac{E_{s}}{0,85 E_{c m}}$. In formulae (6) slip between reinforcement and concrete and strains of concrete in cracked intervals of a beam are taken in to account.

Using formulae (1) and (6) factor

$$
K_{I, 2}=\frac{3,2 f_{c t} \sqrt{t}}{A_{s} \alpha}\left(\frac{S-A h_{c r, a c t}}{h_{c t}}-A-\frac{N_{t o t}}{2 f_{c t}}\right) .
$$

C. Bosco and A. Carpinteri [6] proposed such formula for determination of stress intensity factor:

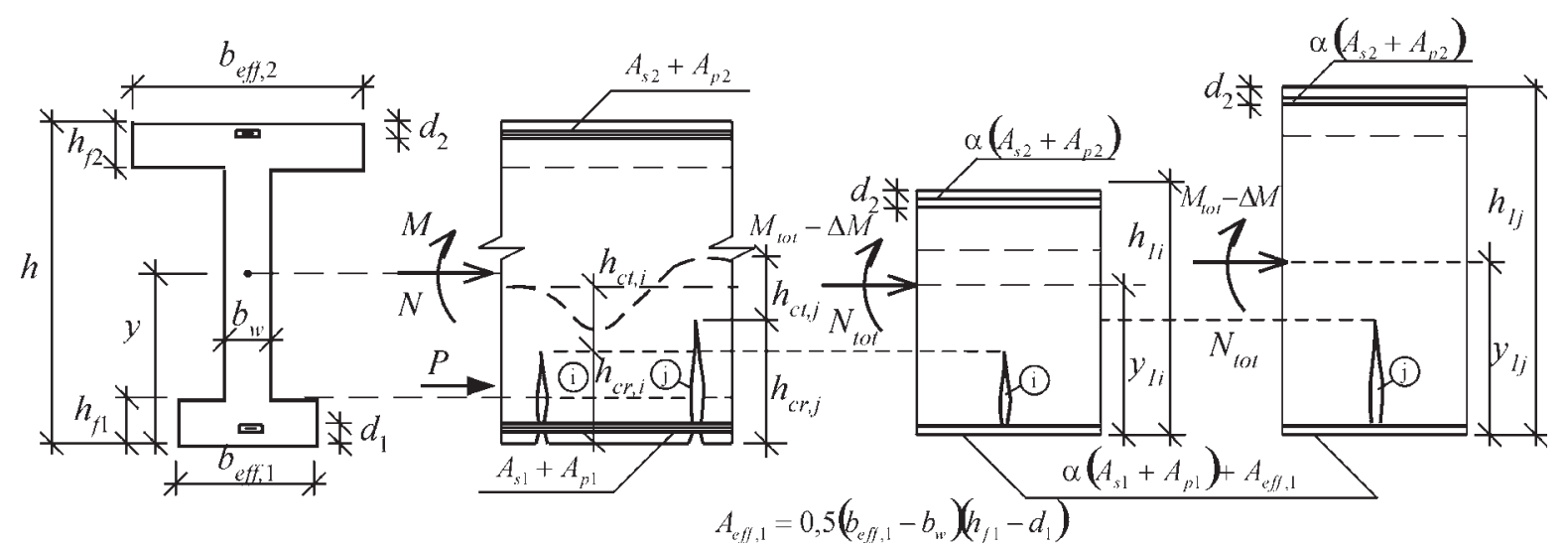

Fig 1. Diagrams for determination of stress intensity factor: a - cross-section of member and its interval with cracks; $b$ design case, when $h \geq h_{1} ; \mathrm{c}-$ design case, when $h<h_{1}$ 


$$
\begin{aligned}
K_{I, 3}= & K_{I M}-K_{I p}=\frac{M}{h \sqrt{h} \cdot b} y_{m}\left(\alpha_{1}\right)- \\
& \frac{\sigma_{s} A_{s}}{\sqrt{h} \cdot b} y_{p}\left(\alpha_{1}, \beta_{1}\right)
\end{aligned}
$$

here $M$ - bending moment in the zone of the beam in pure bending; $y_{m}\left(\alpha_{1}\right)$ and $y_{p}\left(\alpha_{1}, \beta_{1}\right)$ - functions to allow for geometrical parameters of the crack and crosssection $\left(\alpha_{1}=h_{c r} / h, \beta_{1}=d_{1} / h\right)$. Restraining effect of tensile reinforcement on propagation of the crack is evaluated by the factor $K_{I p}$.

\section{Analysis of factor $K_{I}$ variation}

Bond between reinforcement and concrete is one among other effects influencing propagation of cracks in reinforced concrete members. In calculation of stress intensity factor $K_{I, 1}$ according to formula (3) this effect is evaluated indirectly via normal crack parameters $h_{c r}$ and $w$ (see formula (5)). Damages of this bond (slip between reinforcement and concrete) can result in changes of factor $K_{I}$ value. Data of known investigations of cracked intervals of reinforced concrete beams, among them and these of [9], proved that damages to bond between reinforcement and concrete are not significant for calculated values of $\sigma_{s}$. Influence of bond quality is greater in the initial stage of cracking of members, especially when their reinforcement ratios are small.

Theoretical analysis of stress intensity factors was performed using results of investigations [9, 10], which include underreinforced beams of rectangular cross-section. Concrete and reinforcement strengths, reinforcement ratios and magnitude of normal cracks $\lambda=1-\left(h_{c r}-d_{1}\right) / h$ of these beams varied in very large ranges.

In case when crack width $w$ data were not available in investigations [9], depth of concrete tensile zone above the crack $h_{c t}$ for formulae (3) ir (7) was calculated using formulae (6). It has been proved by experiments that calculated $h_{c t}$ and experimental $h_{c t, a c t}$ values are sufficiently close.

Values of stress $\sigma_{s}$ in formula (8) were taken the same as those in calculating of $K_{I, 1}$ values.

Slip between reinforcement and concrete was taken into account in calculations of $K_{I, 1}$ values for reinforced silicate concrete beams by the means of multiplication of stress value in prestressed reinforcement by coefficient 0,67 [11].

For analysis of factor $K_{I}$ the following data of investigations [10] were used: cross-sectional parameters of beams, relative compression zone depth $\xi$ (related to rectangular stress diagram in stage of incipient failure of the beams), concrete cube strength $f_{c, \text { cube }}$, yield stress of reinforcement $f_{y}$ and values of bending moments in beams in the stage of their incipient failure. In this case the lacking values $h_{c r}, h_{c t}, E_{c m}$ ir $f_{c t}$ were determined from such expressions:

$$
\left.\begin{array}{l}
h_{c r}+h_{c t} \approx h-1,25 \xi h_{0}, \\
h_{c t} \approx 2 \alpha\left(h_{c r}+h_{c t}\right) f_{c t} / f_{y}, \\
f_{c t} \approx 5 f_{c, c u b e}\left(45+f_{c, \text { cube }}\right), \\
E_{c m}=55000 f_{c, \text { cube }}\left(27+f_{c, \text { cube }}\right) .
\end{array}\right\}
$$

Values of $f_{c, \text { cube }}$ are taken in $\mathrm{MPa}$.

Values of factor $K_{I, 1}$ ir $K_{I, 2}$ coincide very well for beams reinforcement of which is not prestressed $(P=0)$; greater difference between these values is obtained for prestressed concrete beams $\left(K_{I, 1}>K_{I, 2}\right.$, except for beam No 5, which failed in shear).

Values of factor $K_{I, 3}$ in average are about 1,32 times greater than those of $K_{I, 1}$ (Table), ie resistance of reinforced concrete beams to propagation of normal cracks according to the method [6] is less when values of acting stresses $\sigma_{s}$ are equal in both types of beams. Differences between values of factors $K_{I, 1}$ and $K_{I, 3}$ increase not significantly with stress in longitudinal reinforcement.

Propagation of normal cracks is restrained not only by tensile reinforcement. Their propagation is impeded, especially in the stage close to failure of the member, by transverse strains of concrete in compression zone. Due to these strains microcracks directed along the beams occur, which later merge and develop in longitudinal macrocracks in the stage before final failure of the beam. Propagation of normal cracks slows down and increase of stress in tensile reinforcement intensifies with approach of state of stress in concrete member to the limit of failure. Factor $K_{I 3}$ according to (8) evaluates this effect only partially, since value of $K_{I M}$ is determined from tests of plain concrete beams with the zone of pure bending. In bending members of plain concrete there is not enough time for transverse of concrete strains to come into play and therefore their influence on propagation of normal cracks is less. According to the model presented in [1], propagation of crack is restrained not only by tensile reinforcement but also by transverse strains of concrete in compression zone. In this way it is possible to explain the increase in difference between values of factors $K_{I 1}$ and $K_{I 3}$ with approach to the failure limit of the member.

Nevertheless, it suffices to increase the factor $K_{I p}$ in formula (8) by 3-7\% (or adequately to reduce value of $K_{I M}$ ) for values of $K_{I, 3}$ to become equal to these of $K_{I, 1}$.

There is a relationship between parameters $K_{I} / \mathrm{b}$ and 1 (Fig 2), here $K_{I}=K_{I, 1}$ and $\beta=0,02 f_{y} \sqrt{t}$.

Relationship between parameters $K_{I} / \mathrm{b}$ and 1 can be expressed as follows:

$$
K_{I}=11,37 \beta\left(1-1,3 \lambda^{1,63}\right)
$$

here $K_{I C} \geq K_{I} \geq 70 \beta(1-0,2 \rho) \alpha$.

Value of factor of stress intensity $K_{I}$ increases with normal crack depth and in the stage of failure of beams, the critical value of the factor is attained $\left(K_{I} / \beta \approx 8-11\right.$ for beams of rectangular cross-section [10], Fig 2). The 
Stress intensity factors $K_{I}$

\begin{tabular}{|c|c|c|c|c|c|c|c|c|c|c|c|c|}
\hline \multirow[t]{2}{*}{$\begin{array}{l}\text { Beam } \\
\text { No }\end{array}$} & \multirow[t]{2}{*}{$\begin{array}{c}b \times h, \\
\mathrm{~m}\end{array}$} & \multirow[t]{2}{*}{$\begin{array}{l}\rho, \\
\%\end{array}$} & \multirow[t]{2}{*}{$\begin{array}{l}f_{c t}, \\
\mathrm{MPa}\end{array}$} & \multirow[t]{2}{*}{$\begin{array}{c}f_{y}, \\
\mathrm{MPa}\end{array}$} & \multirow[t]{2}{*}{$\begin{array}{c}M, \\
\mathrm{kNm}\end{array}$} & \multirow[t]{2}{*}{$\begin{array}{l}P, \\
\mathrm{kN}\end{array}$} & \multicolumn{3}{|c|}{$\begin{array}{c}K_{I} \\
\mathrm{MPa} \mathrm{m}^{1 / 2}\end{array}$} & \multirow{2}{*}{$\frac{K_{I, 1}}{K_{I, 2}}$} & \multirow{2}{*}{$\frac{K_{I, 1}}{K_{I, 3}}$} & \multirow{2}{*}{ Notes } \\
\hline & & & & & & & $K_{I, 1}$ & $K_{I, 2}$ & $K_{I, 3}$ & & & \\
\hline \multirow{3}{*}{1} & \multirow{9}{*}{$0,2 \times 0,4$} & \multirow{3}{*}{0,54} & \multirow{6}{*}{0,90} & \multirow{9}{*}{445} & 14,9 & \multirow{9}{*}{0,0} & 0,92 & 0,91 & 1,03 & 1,01 & 0,89 & \multirow{13}{*}{$\begin{array}{l}\text { Calculation } \\
\text { examples; } \\
\text { parameters } h_{c r} \text { and } \\
h_{c t} \text { calculated } \\
\text { according to [7] }\end{array}$} \\
\hline & & & & & 29,8 & & 1,82 & 1,89 & 2,50 & 0,96 & 0,73 & \\
\hline & & & & & 49,6 & & 3,07 & 3,09 & 4,23 & 0,98 & 0,73 & \\
\hline \multirow{3}{*}{2} & & \multirow{3}{*}{1,56} & & & 34,3 & & 1,37 & 1,38 & 1,73 & 0,99 & 0,79 & \\
\hline & & & & & 68,5 & & 2,75 & 2,86 & 3,63 & 0,96 & 0,76 & \\
\hline & & & & & 114,2 & & 4,51 & 4,78 & 6,64 & 0,94 & 0,68 & \\
\hline \multirow{3}{*}{3} & & \multirow{3}{*}{2,53} & \multirow{3}{*}{1,20} & & 49,4 & & 1,96 & 2,05 & 2,56 & 0,96 & 0,77 & \\
\hline & & & & & 98,8 & & 3,95 & 3,94 & 5,49 & 1,00 & 0,72 & \\
\hline & & & & & 164,6 & & 6,64 & 6,32 & 9,10 & 1,05 & 0,73 & \\
\hline \multirow{4}{*}{4} & & & & & 86,4 & & 2,38 & 1,76 & 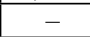 & 1,35 & - & \\
\hline & $0,18 \times 0,5$ & 1,80 & 2,50 & 588 & 106,4 & 230,0 & 3,21 & 2,68 & 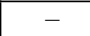 & 1,20 & 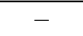 & \\
\hline & & & & & 126,4 & & 3,96 & 3,56 & 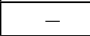 & 1,11 & 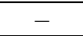 & \\
\hline & & & & & 146,4 & & 4,64 & 4,47 & - & 1,04 & - & \\
\hline 5 & $0,08 \times 0,3$ & 1,18 & 3,57 & 1194 & 25,0 & 33,3 & 5,16 & 5,72 & - & 0,90 & - & According to data \\
\hline & & & & & 31,3 & & 5,80 & 7,40 & - & 0,78 & 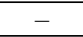 & of [7]; \\
\hline 6 & $0,08 \times 0,18$ & 2,03 & 1,50 & 286 & 6,3 & 0,0 & 2,11 & 2,25 & - & 0,94 & - & experimental \\
\hline & & & & & 7,3 & & 2,46 & 2,57 & 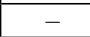 & 0,96 & 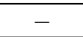 & $h_{c r, a c t}$ values \\
\hline 7 & $0,105 \times 0,185$ & 0,88 & 1,65 & 588 & 29,4 & 75,0 & 0,56 & 0,45 & 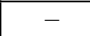 & 1,24 & 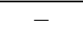 & According to data \\
\hline & & & & & 47,2 & & 0,98 & 0,70 & - & 1,40 & - & of [7]; \\
\hline 8 & & 1,90 & & & 7,9 & & 0,96 & 0,94 & - & 1,02 & - & Reinforced silicate \\
\hline & $0,105 \times 0,188$ & & 1,67 & 358 & 11,0 & 0,0 & 1,35 & 1,33 & - & 1,02 & - & concrete beams; \\
\hline 9 & & 3,22 & & & 8,8 & & 0,72 & 0,77 & - & 0,94 & - & $h_{c r a c t}$ values \\
\hline & & & & & 13,9 & & 1,15 & 1,24 & $\begin{array}{llll}- & \\
\end{array}$ & 0,93 & $\begin{array}{llll}- & & & \end{array}$ & applied \\
\hline 10 & & 2,42 & 2,12 & 356 & 83,8 & & 5,31 & & verage: & 1,03 & 0,76 & \\
\hline 11 & & 0,49 & 2,82 & 354 & 24,5 & & 2,63 & & & & & According to data \\
\hline 12 & & 0,51 & 2,86 & 355 & 25,3 & & 2,71 & & & & & of [8] \\
\hline 13 & & 1,50 & 2,62 & 362 & 55,6 & & 3,74 & & & & & \\
\hline 14 & & 2,50 & 2,62 & 363 & 83,8 & & 5,50 & & & & & \\
\hline 15 & & 1,26 & 3,45 & 354 & 50,8 & & 3,21 & & & & & \\
\hline 16 & $0,15 \times 0,3$ & 2,65 & 3,31 & 366 & 83,8 & 0,0 & 5,76 & & & & & \\
\hline 17 & & 3,75 & 3,50 & 358 & 133,3 & & 6,92 & & & & & \\
\hline 18 & & 0,52 & 2,30 & 1043 & 62,8 & & 7,69 & & & & & \\
\hline 19 & & 0,52 & 3,45 & 1040 & 77,8 & & 8,12 & & & & & \\
\hline 20 & & 1,03 & 3,34 & 1054 & 124,3 & & 9,48 & & & & & \\
\hline 21 & & 2,51 & 3,37 & 835 & 161,8 & & 13,02 & & & & & \\
\hline
\end{tabular}

imits of validity for formula (10) indicate that value of factor $K_{I}$ depends on reinforcement ratio $\mathrm{r}$ of underreinforced beams. Interval of application of formula (10) decreases with reinforcement ratio of beams. However, relationship (10) valid for beams up to their failure stage (when $\sigma_{s}=f_{y}$ ) gives an opportunity to evaluate danger of open normal cracks for existing concrete structures.

\section{Conclusions}

1. Different from plain concrete structures, propagation of normal cracks in reinforced concrete structures is stabilised by tensile reinforcement and transverse strains of concrete in compression zone. Therefore propagation of such macrocracks with sufficient accuracy can be controlled by the means of one general for reinforced concrete stress intensity factor $K_{I}$ expressed via tensile reinforcement stress $\sigma_{s}$, reinforcement ratio $\rho$ and location of reinforcement in cross-section of the member. Resistance of tensile concrete to propagation of the crack, in comparison with just mentioned effects restraining propagation of crack, is not significant. 
2. Stress intensity factor $K_{I}$ in underreinforced concrete beams can be calculated by (3) or (7) formulas. Factor $K_{I}$ can be approximately calculated more simply by the means of established direct relationship between values of $K_{I}, h_{c r}, t, f_{y}$ and a (formula (10)). Application of such type of relationships is convenient for assessment of existing reinforced concrete structures with cracks.

\section{References}

1. Jokūbaitis, V.; Kamaitis, Z. Cracking and repair of reinforced concrete structures (Gelžbetoninių konstrukcijų pleišèjimas ir remontas). Vilnius: Technika, 2000. 155 p. (in Lithuanian).

2. Bazant, Z. P.; Ozbolt, J.; Eligchausen, R. Fracture size effect: Review of evidence for concrete structures. Journal of structural engineering, Vol 120, No 8, August 1994, p. 2377-2398.

3. Denaru, E.; Soouna, V. E.; Iocco, A.; Varelas, D. Concrete fracture process zone characterisation with fibber optics. Journal of structural engineering mechanics, Vol 127, No 5, May 2001, p. 494-502.

4. John, R.; Shah, S. P. Fracture mechanics analysis of highstrength concrete. Journal of materials in civil engineering, Vol 1, No 4, Nov 1989, p. 185-198.

5. Piradov, K. A.; Guzejev, E. A. Method for evaluation of stress-strain state in reinforced concrete members via pa- rameters of fracture mechanics. Concrete and reinforced concrete (Бетон и железобетон), 1994, № 5, p. 19-23 (in Russian).

6. Karihaloo, B. L. Fracture mechanics and structural concrete. Concrete design and constructions series. Longman Scientific and Technical, 1995. $330 \mathrm{p}$.

7. Jokūbaitis, V.; Jurkša, A. Modelling formation and development of longitudinal cracks in concrete crossing corroding reinforcement. Journal of Civil Engineering and Management, Vol VII, No 3. Vilnius: Technika, 2002, p. 159-163.

8. Jokūbaitis, V.; Kamaitis, Z. Shear cracks modelling for assessing the stresses in concrete shear reinforcement. Journal of Civil Engineering and Management, Vol VII, Suppl 1. Vilnius: Technika, 2002, p. 24-28 (in Lithuanian).

9. Rozenbliumas, A. Calculation of reinforced concrete structures taking into consideration concrete tensile stresses. In: Investigation of reinforced concrete structures (I) (Исследования железобетонных конструкций). Vilnius: Mintis, 1966, p. 3-32 (in Russian).

10. Mulin, N. M.; Gushcha, J. P.; Mamedov, P. Ch. Strength of beams and their deformations in the stage close to failure. In: Innovations in strength of reinforced concrete (Новое в проектировании железобетонных конструкций). Moscow: Strojizdat, 1977, p. 30-47 (in Russian).

11. Concrete and reinforced concrete structures from dense silicate concrete (СНиП 2.03.02-86. Бетонные и железобетонные конструкции из плотного силикатного бетона). Moscow, 1987. 22 p. (in Russian).

\section{IŠILGINĖS ARMATŪROS ITTAKA NORMALINIŲ PLYŠIŲ PLITIMUI}

\section{Jokūbaitis, P. Pukelis}

Santrauka

Pagal normalinio plyšio plitimo modeli gelžbetoniniame elemente galima apskaičiuoti tempiamosios armatūros įtempius. Pateikiama įtempių intensyvumo koeficiento, nusakančio įtempių lauko intensyvumą, analizinè išraiška. Šis koeficientas tiesiogiai proporcingas tempiamosios armatūros įtempiams. Itempių intensyvumo koeficiento reikšmès buvo tarpusavyje palygintos ir pagal skirtingas metodikas apskaičiuoti tempiamosios armatūros įtempiai. Analizė parodè, kad egzistuoja aiški priklausomybė tarp ịtempių intensyvumo koeficiento ir normalinio plyšio aukščio (ilgio), kai baigiasi nestabilus plyšiu plitimas elemento pleišèjimo pradžioje. Be to, šios priklausomybès išraiškai didelès reikšmès turi neperarmuotu sijų armavimo koeficientas.

Raktažodžiai: ittempiai, tempiamoji armatūra, normaliniai plyšiai, ittempių intensyvumo koeficientai.

Vidmantas JOKŪBAITIS. Doctor, Associate Professor. Dept of Reinforced Concrete and Masonry Structures. PhD (1960, civil engineer) at Kaunas Technological University. Assoc Prof (1967). Research interests: evaluation of reinforced concrete structures with cracks of existing buildings.

Petras PUKELIS. Doctor, Associate Professor. Dept of Reinforced Concrete and Masonry Structures. Doctor (1963, building structures KPI). Since 1971 at VGTU. Co-author of 2 textbooks. Lithuanian state prize winner. Author of numerous publications on concrete and masonry structures. Research interests: shear strength of concrete structures, assessment and renovation of concrete and masonry structures, implementation of Eurocodes. 